\title{
Economic Liberalization in Liberia and Its Effects on Unemployment and Economic Growth
}

\author{
Alieu Mohammed Massaley \\ Shanghai University, Shanghai, P. R. China
}

\begin{abstract}
This study sought to establish the status of economic liberalization in the modern Liberia and its impact on unemployment rate and economic growth. The study established different forms of economic liberalisation in Liberia: Liberalization of state owned enterprises, encouragement of free trade, increased deregulation of expert and import as well as regional trade, encouragement of open markets, reduction in taxation brackets, and abolition of trade tariffs and price controls. The study also established that economic liberalisation was significantly associated to reduction in unemployment rate and an increase in economic growth. The study recommends that the new leadership in Liberia should allow for local ownership of SOEs through floating them in the stock exchange through the initial Public Offer (IPO), as well as monitoring its macro- and micro fiscal policies to encourage local production and consumption.
\end{abstract}

Keywords: Economic Liberalization, Economic Growth, Unemployment, State-Owned Enterprises.

DOI: $10.7176 / \mathrm{JESD} / 10-18-07$

Publication date:September $30^{\text {th }} 2019$

\subsection{Introduction}

Economic liberation refers to the process that includes the government policies whose aim is to promote free trade among various nations, deregulation, the elimination of the subsidies, price controls in the country privatization of the state owned enterprises. Since the late 1970s, economic liberation has been key in the developing countries as a condition for lending from the international financial institutions such as the IMF. Economic liberalization argues that the government should take a laissez-faire approach in running the economy and rely on the market sources to allocate resources rather than directing the market(Besley, 2004; Tollison, 2012). The argument of this policies has been that such an adjustment will be able to reduce poverty and spur growth in these countries. It is from this perspective that the intervention of the government in the market is seen as both inefficient and has distortionary effect. The argument made above is that even if the intention of such a state is good, the state do not have the competence to manage the economy well. Liberia has not implemented the trade liberalization effectively and this will impact its national policy on the elimination of poverty and growth(Moumouni, 2018). This paper looks at the status and the potential benefits of the economic liberation on the country

\subsection{Status of Economic Liberalisation in Liberia}

The state of the Liberian economy can be described as being fragile ever since the first protest over prices of rice in April 1979 that caused widespread looting and violent crackdown on dissidents in the country. In the same year, a 28 year old Samuel Doe led a coup on the government and killed the then president, William Tolbert leading to a series of chaos and political turmoil that culminated in the Liberian Civil war(Brandon, 2018). Ever since 2003, the country has been recovering its fragile economic status with support from the US and the government of Nigeria. Since the election of the president Ellen Johnson Sir leaf, the country has embarked on a pro-growth and poverty eradication reforms to help the economy of the country to fully recover. Economic liberation in the country has been hard to implement due to the civil war and the political turmoil(De Melo \& Mancellari, 2014). However, some sectors of the economy have benefited from economic liberalization while some sectors have not been fully liberalized.

\subsection{Privatisation of SOE}

There exists a number of state owned enterprises in Liberia. The history of the state owned enterprises in the country has been dark marked with high corruption by those appointed to head the institutions, cronyism and state mismanagement of resources. However, after the end of the civil war, the government has taken steps towards salvaging the situation. Some of the reforms that the government has taken includes giving a number of the SOEs and the autonomous agencies minimal budgets that will see them getting dissolution(Kassim, 2015). Secondly, the government since 2012 has embarked on a journey to privatize the SOEs. The SOEs that has been privatized in the country are those that have become obsolete, unnecessary or those that the government deems to be appropriate for the private ownership. The process of privatisation has had its share of advantages and disadvantages. Whereas Liberia is in the process of recovering from the effects of the civil war(Moumouni, 2018), trade privatisation was the only means of ensuring efficiency and effectiveness in managing government enterprises. 


\subsection{Free Trade}

Free trade is defined as the composite measure of the tariff and the non-tariff and import and the exports in terms of the goods and the services in the country. The trade freedom is measured by the trade-weighted average tariff rate and the non-tariff barriers. The different imports that enters Liberia can and still faces different forms of tariffs. The weighted average tariff allocates each tariff based on the import that is given to each good. The government has enhanced direct intervention in the country to ensure that free trade has been achieved(Kassim, 2015). Free trade has been implemented in the country although the government has entered into trade agreement with the members of the regional bodies as well as the United States which stands as its oldest trading partner.

\subsection{Deregulation}

Deregulation in Liberia has been felt more in the cocoa market where the country has opened its doors to more buyers and has increased the competition among the various buyers. Deregulation is one of the changes that the government has put in place since the end of the civil war to ensure that the country recovers and restructures(Beekman, Bulte, \& Nillesen, 2013). This move has been able to improve the business opportunities for the smallholder cocoa farmers who have been able to sell their products. The rules of the cocoa market have changed in the post-war period. With the decision of the government in 2009 to deregulate most of its sectors in the economy, the country is now open to sell their products to a number of buyers. Firms have been given the sole purchasing rights of the agricultural products thus spurring growth and helping in the eradication of poverty(Beekman et al., 2013; Kassim, 2015). The buyers in the market with a strong market power could dictate the prices for small business owners and thus help them to spur growth.

\subsection{Open Markets}

The combined value for the exports and the imports in the country is given to be equal to 121.7 percent of the GDP. The World Bank in a 2011 report indicates that they applied tariff rates in the country stands at 12.4 percent (Kassim, 2015). The reforms that has been taken by the government have been able to dismantle the barriers to trade. However, there still exists a lack of transparency in the open markets. Foreign investment in the several sectors of the economy is restricted as the foreign investors might be able to own a land in the country. Ownership rights is one of the fundamental factor that allows growth and as such, there exists reforms in this sectors(Kassim, 2015). The property rights in the country is not well represented and the manner of enforcing the contracts is a lengthy process. While the judiciary is independent, it is weak and largely underscored due to the pervasive corruption and the lack of administrative capacity to handle issues in the country. The following graph with data source from ww.heritage.com that measures economic freedom across the world identifies that Liberia is trailing behind in property rights enforcement.

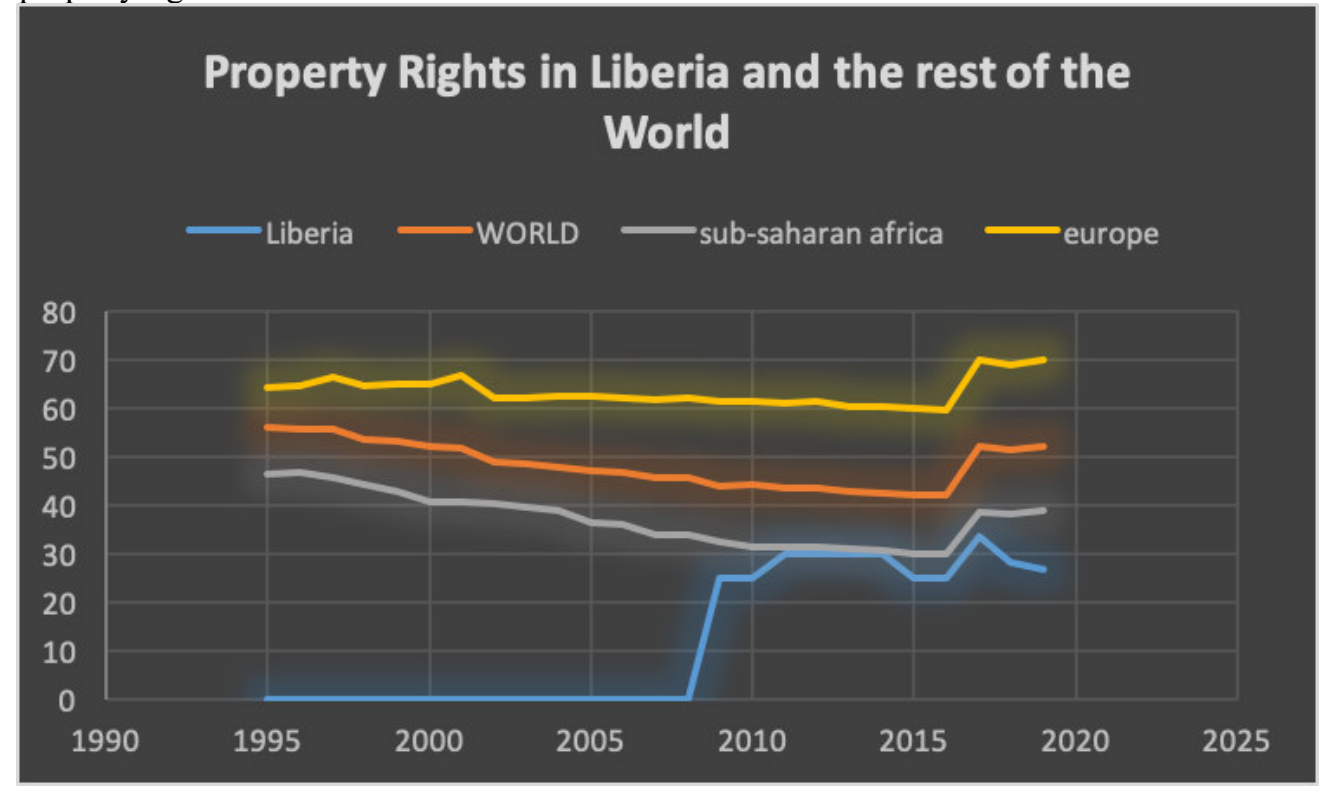

Source: https://www.heritage.org/index/country/liberia

\subsection{Lower Taxation for Business}

The government has in the recent past simplified the process of paying taxes in the country. However, the simplification tax process and ensuring that the taxes do not accumulate in the country. There exists leakages in the current tax system in Liberia which increases internal debt and increases foreign borrowing(Beekman et al., 
2013; Brandon, 2018). This occurs as a result invoicing and the collusion, tax fraud and the discretionary assessment. There is a need to broaden the tax base to areas with great untapped areas of the economy such as the tourism and the real estates(Kassim, 2015). The government needs to undertake clear financial management reform to ensure that there exists a lower taxation system that takes care of the needs of the business of all sectors of the economy, not only the high end business but also the lower level business to ensure transparency and encourage growth of business. Corporate tax in the country is fixed at $25 \%$. Other taxes that exists includes the property and good taxes. In the last 3 years, the government spending has amounted to $35.5 \%$ of the total GDP and the budget deficit have averaged $4.2 \%$ of the total GDP. Public debt stands at $34.4 \%$ of the GDP.

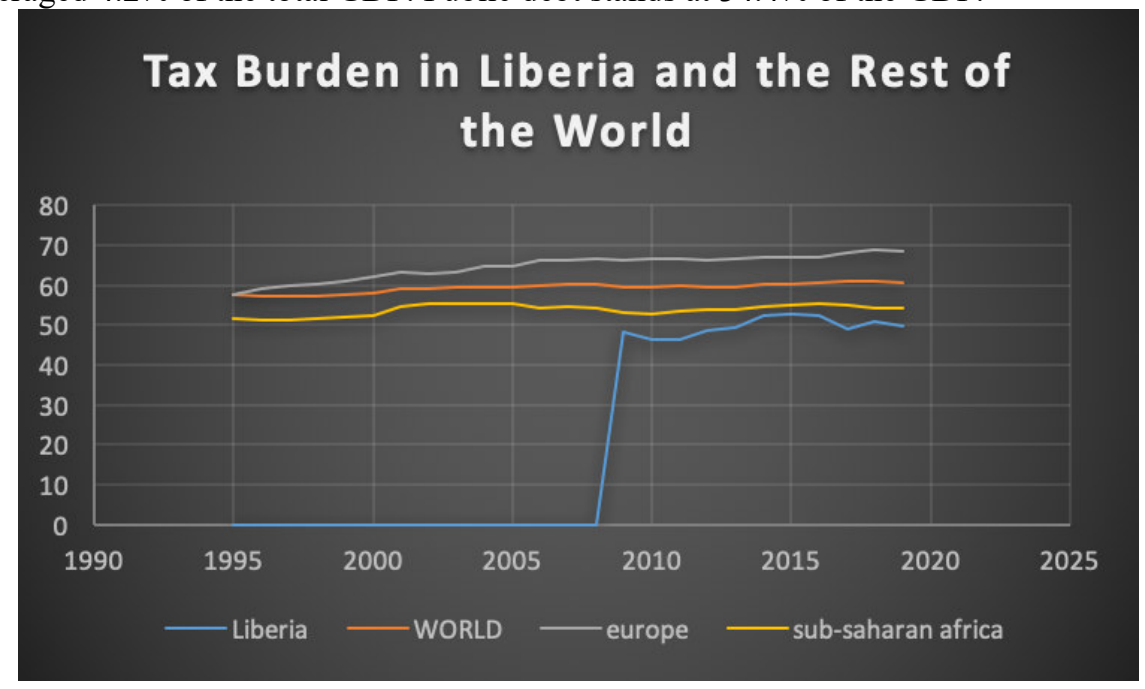

Source: https://www.heritage.org/index/country/liberia

\subsection{Benefits of Economic Liberalization in Liberia}

Economic liberalisation in Liberia has immense benefits to the country coming at a time when the state is recovering from the fragile economic and political environment. Trade reforms is often followed by small decrease in the value but will generally open up the economy to foreign investment that will be able to spur growth creating jobs and eventually eradicating poverty(Moumouni, 2018). While it is frequently claimed that trade liberation comes at a costs of increased economic vulnerability as a result of the deindustrialization and the concentration of the exports in few products. Brandon (2018), identifies that this shocks and vulnerabilities of the trade are minimal and its effect can be controlled. In the midst of both the international and the regional trade liberalization in the multilateral, bilateral and the regional levels, it is important to look at the cross-country evidence when identifying the benefits of the trade openness and the eventual economic development(Vivenza, 2001). Liberia can learn from other countries that has been able to accelerate economic growth through trade liberation and trade reforms that did not bring doomsdays for this countries but have rather ensured that trade reforms made important contribution to achieving sustained development in these countries.

\subsection{Removing Barriers to International Investing}

Investing in emerging countries can be an uphill task if the country that one aims to invest in as several barriers to the entry. Some of the barriers that might chase away investors includes the existence of punitive tax laws, restrictions on foreign investments, legal issues with property acquisition and the accounting regulations that makes it hard for the foreign investors to invest in the country. Economic liberalization is an instrumental tool that opens up the country to the international market in terms of policy regulations, trade taxation and other areas that ill generally affect the country(Moumouni, 2018). As a rule of the thump, one is able to determine the level of economic liberalization in the country by checking the ease with which one can invest in. all the developed countries have gone through trade liberalization and thus it is fundamental for Liberia to go through the same(De Melo \& Mancellari, 2014). This can be achieved through removal of the trade barriers and relinquishing the control of the economy.

\subsection{Unrestricted Capital flow}

The main aim of economic liberation is to achieve a free flow of the capital between the nations and the allocation of resources within the country that would allow for a competitive advantage. Unrestricted flow of capital can be achieved in Liberia by reducing the protectionist policies that exists in the country such as the trade laws and the trade barriers(Cooper, 2002; Kassim, 2015). The increased flow of capital has immense effect for a country has it will allow for the companies to access capital from the investors in the country. Such a low cost of capital for this 
companies will allow for them to undertake projects that they might not have been able to achieve with a higher cost of the capital before the liberalization process began. In the 1970s China began trade liberalization that saw the country privatized its companies, relaxed the trade policies and removing foreign investment restrictions that saw the country achieve a phenomenal GDP growth (Brandon, 2018).

\subsection{Stock Market Performance}

When the country becomes liberated, stock market value in the country also rises. In essence fund managers and investors in the country are always on the lookout for new business to invest in. when a new market becomes liberalized, it presents an opportunity for these investors to come and make investment in the country thus causing an up surge in the capital to flow into the country(Cooper, 2002; Steinberg, 2003). Trade liberalization in a country can be likened to the anticipation and the flow of money in the initial public offering. The country will be able to show a cash flow pattern similar to such a company and thus this will be able to spur growth. The initial enthusiasm will eventually die and the returns will return to normal.

\subsection{Reduction of Political Risks}

Trade liberalization has tremendous effect in reducing the political risks for the investors in the country. Liberia has been described as being a fragile state, its fragility largely due to the political factors and the civil war. However, the ending of the civil war has had its fair share of promise to the investors. The political risks in the country makes the loose hope in investing in the country. There exists areas in which the government needs to improve on that will support and foster the willingness of people to do business in the country(Brandon, 2018). These factors include the legal foundations that will enable a seamless dispute resolution process that is fair and ensures that the contract laws and the property laws within the country are enforced that would allow the investors to do business in the country with confidence.

\subsection{Investor Portfolio Diversification}

With trade liberalization, investors benefit through investing a portion of their assets to another asset class. Correlation between the United States and Liberia is often low. By adding a low correlation asset to the existing portfolio, the investors can reduce their risk profile. With trade liberation, this correlation rises over time(Brandon, 2018). This is possible due to the fact that when a country becomes more integrated with other countries in the world, such a country becomes sensitize to the international events that is happening outside the county. When this integration is high, the contagion risk is also increased on the other hand. Trade liberalization has immense effects on the economy of the given country and thus this will lead to growth in the country.

\subsection{Effects of Economic Liberalization on Various Sectors in Liberia. \\ 4.1. Effects of Trade Liberalization on Unemployment Rates.}

A recent review of the empirical evidence on the effects of trade liberalization on the economy of a country has concluded that trade liberalization has resulted in both an increase and a decline in the growth rate depending on country circumstances(Dev, 2000). Many countries were observed to have experienced an investment slump after trade liberalization, suggesting that a "J-curve" effect is at work. This suggests that there are at least short-run costs of adjustment after trade liberalization. Trade liberalization has also tended to be associated with an increase in current account deficits in spite of an increase in exports. These mixed results indicate that the impact of trade liberalization is not uniform but, on the contrary, is strongly influenced by factors such as the nature of the liberalization program, the extent of pre-existing distortions in the trade regime and the flexibility of markets. There have been relatively few cross-section studies that focus directly on the impact of trade liberalization on employment. A major World Bank study (Papageorgiou, Choksi and Michaely, 1990) dating back to 1990 attempted to demonstrate the benefits of substantial trade liberalization. Based on the examination of 36 distinct episodes of trade liberalization in 19 countries, it offered very reassuring conclusions about the benefits of trade liberalization. Among its conclusions were the views that "even in the short run liberalization went hand in hand with faster rather than slower growth" and that "trade liberalization did not as a rule raise unemployment even in individual sectors of the economy such as manufacturing and agriculture"(Buchanan \& Tollison, 1984; Steinberg, 2003). It explains the latter outcome in terms of the fact that a slowdown in manufacturing growth was compensated by a rise in agricultural growth and employment as a result of trade liberalization. It also claimed that this increase in agricultural growth, together with the fact that there was an increase in labor-intensive exports, increased the demand for labor overall and hence led to an improvement in income distribution. In Liberia the following model was used to estimate the effect of economic Liberalization on employment rates in Liberia. $\mathrm{Y}=\beta 0+\beta 1+\beta 2+\beta 3+\ldots \beta \mathrm{n}+\alpha$

Where $\beta 0$ is the intercept indicating the effects of economic liberalization in the absence pf determining factors; $\beta 0$ - $\beta \mathrm{n}$ represents the actual indicators of Economic Liberalization. The table below shows the coefficients associated with the descriptive statistics and regression analysis that was carried on the effects of economic 
liberalization on employment rates in Liberia.

Table 1: Descriptive Statistics.

\begin{tabular}{|lrrrr|}
\hline & \multicolumn{2}{c}{ Year 1995 } & \multicolumn{2}{c|}{ Year 2014 } \\
& Unemployment & Openness & Unemployment & Openness \\
\hline Mean & 6.93 & 75.40 & 6.59 & 90.22 \\
S.D. & 4.19 & 48.81 & 3.98 & 58.14 \\
Minimum & 0.40 & 14.80 & 0.30 & 19.10 \\
Maximum & 19.00 & 345.70 & 19.70 & 439.20 \\
N & 89.00 & 89.00 & 89.00 & 89.00 \\
\hline
\end{tabular}

Analysis from year 1995-year 2014.

Table 2: Effect of Economic Liberalization on unemployment in Liberia.

\begin{tabular}{lll}
\hline Dependent & Year 1995(1) & Year 2014(2) \\
\hline Constant & 8.20874 & 7.693709 \\
& $(10.16) * * *$ & $(9.94) * * *$ \\
Openness & -0.016949 & -0.012227 \\
R2 & $(1.87)^{*}$ & $(1.69) *$
\end{tabular}

Absolute value of robust t-statistics is reported in parentheses. * Significant at $10 \%$ level ** Significant at 5\% level *** Significant at $1 \%$ level

The results of regression model (1) of year 2014, which is shown in table 2 could be described that the openness is also negative and significantly correlated to unemployment in year 2014. From table 2, the results dedicated that the coefficient of openness is -0.0122224 with t-value 1.69 , which means from every unit increase in openness, expect a 0.012227 unit decrease in unemployment, holding all other variables constant. Moreover, the coefficient for openness is statistically significant at level $10 \%$ because its t-value is higher than 1.64 . Also, the constant is 7.693709 , this is the predicted value when openness equals zero. So, from the results in year 2015, trade opening has negative correlation with unemployment, which means if countries have higher level of openness, those countries would have the lower rate of unemployment. This findings concur with those of Moumouni (2018) who sought to establish the effect of China-Liberia economic cooperation on internal Liberian economic dimensions.

\subsection{Effects of Trade Liberalization on Economic Growth.}

Kalu et.al (2016) served to determine the impact of trade openness on economic growth in Nigeria for the period 1991 - 2013. In employing the classical linear regression model (CLRM), the study established that export has a positive and significant effect on economic growth while import had a positive but non-significant effect. Another Nigerian study was undertaken by Olufemi (2004) and indicated that there is a unidirectional linkage between trade openness and economic growth. This implies that economic growth in Nigeria depends on trade openness. The main aim of this objective was to analyze the effect of trade liberalization on economic growth in Liberia using annual data from 1990 to 2014. In doing so, the study incorporated Foreign Direct Investment (FDI) and the Employment Rate (EMP) as additional variable to form a multivariate framework. The Auto-Regressive Distributive Lag (ARDL) test was used to test the existence of a long run relationship among the variables. The empirical findings indicated that Trade Openness had a positive and significant effect on economic growth in Liberia. The empirical model used in addressing this objective is as shown below:

$G D P=f(E M P, T O P$,

$F D I)$.

The function can also be represented in an econometric format thus:

$G P D=\beta_{0}+\beta_{1}(E M P)+\beta_{2}(T O P)+\beta_{3}(F D I)+$

tt......................................................................

Where:

GDP: is the growth rate of Gross Domestic Product EMP: shows the percentage of the labor force that is employed;

TOP: is trade openness equal to the sum of imports and exports $(E X+I M)$;

FDI: it shows the net inflows of inward direct investment that are made by investors;

$\boldsymbol{\beta}_{\mathbf{0}}$ : is the constant term, $\mathrm{t}$ is the time trend, $\boldsymbol{\varepsilon}$ is the error term.

From the literature it has been realized that different authors observed that there is a positive relationship between trade openness, foreign direct investment, employment and real GDP. However there are other factors that may influence this relationship(Kassim, 2015). The theoretical literature deduced that trade liberalization impacts a country's economic growth to a greater extent although macroeconomic policies of a country play a 
major role. The theory showed that for a country to benefit from trade liberalization depends on factors such as whether a country uses export-led strategy, if it is labor or capital intensive, if it has a skilled workforce or not, the extent in which the labor force is skilled or experienced to use new technology. The study utilized Unit Root (UR) in the estimation of model. Unit root (which is also called a unit root process or a difference stationarity process) is a stochastic trend in time series, sometimes called a 'random walk with drift' and if a time series has a unit root, it shows a systematic pattern that is unpredictable. To be able to deduce this, this study employed the Augmented Dicker Fuller test (ADF) and the Phillips-Perron to determine unit root. The Augmented Dicky-Fuller (ADF) test was employed to check the stationarity of the variables. ADF is a unit root test that reports the correlation between error terms and includes the lag value of the dependent variable in the regression. The results are shown in the table 3 below.

Table 3: Unit Root Tests.

\begin{tabular}{|c|c|c|c|c|}
\hline & \multicolumn{2}{|l|}{ Levels } & \multicolumn{2}{|c|}{ First difference } \\
\hline Variable & $\overline{\mathrm{ADF}}$ & $\mathrm{PP}$ & $\overline{\mathrm{ADF}}$ & \\
\hline GDP & -2.482 & -1.740 & $-3.678 * *$ & $-3.594 * *$ \\
\hline EMP & 0.474 & 0.593 & $-4.756^{* *}$ & $-5.315 * *$ \\
\hline TOP & -0.305 & -1.968 & $-4.293 * * *$ & $4.277 * * *$ \\
\hline FDI & -1.573 & -5.294 & $-8.175 * *$ & $-12.277 * *$ \\
\hline
\end{tabular}

The results for both ADF and PP show that we fail to reject the null hypothesis of unit root in the level form for all the variables. This implies all the variables have unit root. However, when the two tests are applied to the variables at the first difference, we can reject the null hypothesis of unit root. This means that the variables are stationary at first difference. From Table 4.2, it can be deduced that there is a presence of a long run relationship between economic growth, trade openness, employment and foreign direct investments in Switzerland. This is on account that when economic growth is taken as the dependent variable, the F-statistics of economic growth (15.287) is greater than the upper critical bound value of 4.66 at 1 percent level of significance. This findings are consistent to the results of Dev (2000), and Khobai and Chitauro (2018).

\subsection{Policy suggestions on Economic Liberalization}

Nothing in the foregoing negates the proposition that there are gains from trade and that there are costs associated with protectionism. The issue is not whether countries should try to benefit from freer trade but how this should be achieved. What the preceding discussion has tried to suggest is that there is no basis for a blanket prescription of "big bang" trade liberalization that is applicable to all countries. The relationship between trade liberalization and growth and employment is likely to be "a contingent one, dependent on a host of countries and external characteristics"(Khobai \& Chitauro, 2018). Differences in country circumstances (such as the level of development or whether a country has comparative advantage in primary commodities or manufactures) are likely to warrant different strategies of trade liberalization. More generally, trade liberalization needs to be embedded within a coherent set of macroeconomic, structural and social policies in order to be successful. It needs to be accompanied by complementary policies, such as the maintenance of an appropriate real exchange rate and macroeconomic stability; an institutional environment conducive to the growth of entrepreneurship and productive investment; effective institutions and policies for social protection; well-functioning and appropriately regulated labor, product and financial markets; and measures to enhance the capacity of poor producers and workers in the rural and urban informal sectors to benefit from trade liberalization. This is a clear example of the importance of ensuring coherence between economic and social policies. Since our study evidenced the trade openness contributes to economic growth, it is recommended that the government and the policy makers should pursue the policies that will promote trade openness in Switzerland. This can be achieved by establishing multi-lateral and bilateral trade agreements that are favorable and ensuring environment that will support international trade and appropriate technology transfer.

- The government of Liberia should continue to revise the 2016 amendments if teg LRC. Further, the government needs to look at other options that can be used in closing the financing gap. This implementation should be done in phases, such will lower the tax burden in the country and the potential for the political instability.

- While deregulation has been felt in the agriculture sector in the country, there is a need for the same to be implemented in other sectors of the economy such as the trade and real estate. The deregulation would be able to diversify the economy into the small sector agriculture, fisheries, the tourism sector and the manufacturing sectors.

- There is a need for an immediate priority to be given to land ownership and property laws to be granted and given to the foreign investors. In the country, land ownership is restricted for the foreign investors as this will be able to boost the ease of doing business in the country. 
- While the country has enacted free trade through bilateral and the multilateral ties with the regional and the international partners, this is still a grey are in policy framework. Economic liberalization is meant to open up the country to foreign investment and as such, there is a need to not limit this to strategic partners but also engage with other countries that the country has not done any business with before.

\subsection{Conclusions}

Economic liberalization is beneficial and desirable process for both the emerging ad he developed countries. The goal of the trade liberalization is to achieve unrestricted capital flow from one country to another with an aim of boasting the economy and the growth efficiency of this countries. Liberia has in past not been able to fully implement the trade liberalization fully despite the immense potential of the economic liberalization in the country. If the country is increase growth, then there is a need for changes to be effected. The main effects of the liberalization is the interest of the investors as they are provided with an opportunity to diverse in the market and create profit in the country. Economic liberalization is 9impoartnt as it opens up the country for international investing, diversification of the business portfolio and taming the political risks in the country.

\section{References.}

Beekman, G., Bulte, E. H., \& Nillesen, E. E. (2013). Corruption and economic activity: Micro level evidence from rural Liberia. European Journal of Political Economy, 30, 70-79.

Besley, T. (2004). Welfare economics and public choice The encyclopedia of public choice (pp. 933-937): Springer.

Brandon, J. D. (2018). Challenges to economic growth in post-conflict enviroments: new trends in human capital loss, aid effectiviness, and trade liberalization.

Buchanan, J. M., \& Tollison, R. D. (1984). The Theory of public choice--II: University of Michigan Press.

Cooper, N. (2002). State collapse as business: The role of conflict trade and the emerging control agenda. Development and Change, 33(5), 935-955.

De Melo, J., \& Mancellari, A. (2014). Regional and Global Trade Strategies for Liberia.

Dev, M. (2000). Economic liberalisation and employment in South Asia: ZEF Discussion Papers on Development Policy.

Kassim, L. (2015). The impact of trade liberalization on export growth and import growth in Sub-Saharan Africa Regional Integration and Trade in Africa (pp. 47-68): Springer.

Khobai, H., \& Chitauro, M. (2018). The Impact of Trade Liberalisation on Economic Growth in Switzerland.

Moumouni, G. (2018). China and Liberia: Engagement in a Post-Conflict Country (2003-2013) China and Africa (pp. 225-251): Springer.

Steinberg, R. (2003). Economic theories of nonprofit organizations The study of the nonprofit enterprise (pp. 277 309): Springer.

Tollison, R. D. (2012). The economic theory of rent seeking. Public Choice, 152(1-2), 73-82.

Vivenza, G. (2001). Adam Smith and the classics: the classical heritage in Adams Smith's thought: Oxford University Press. 